\title{
'Conversações do papel e para o papel': ressonâncias machadianas na obra de Carlos Drummond de Andrade
}

MARCELO DA ROCHA LIMA DIEGO

Princeton University

\begin{abstract}
In the present essay, I examine the place of Machado de Assis within the Brazilian literary system by comparing and contrasting his work with that of Carlos Drummond de Andrade. I outline four types of dialogue taken up between the two authors: 1) a shared profession of faith; 2) common poetic-existential identification; 3) the "resumption of paradigms"; and 4) the "resumption of syntagmata," that is, the reoccurrence of textual quotations of or direct allusion to Machado's fiction in Drummond's poetics.
\end{abstract}

Keywords: Brazilian literature; intertextuality; intratextuality; literary system; literary genres

O estudo da obra de Machado de Assis em perspectiva intertextual vem demonstrando, já há algum tempo, como a convocação de outros textosprincipalmente dos clássicos-para dentro de si é um dos elementos que conferem à prosa machadiana seu traço de universalidade e a inserem no circuito de legitimação a que pertencem esses textos. ${ }^{1}$ Em outras palavras, vem

\footnotetext{
${ }^{1}$ A versão atual deste ensaio deve muito à leitura atenta de Pedro Meira Monteiro e Marta de Senna, bem como às informações em primeira mão fornecidas por Hélio de Seixas Guimarães e aos conselhos de Victor Heringer. A todas essas pessoas, o meu mais sincero agradecimento.
} 
demonstrando como é ao reler o cânone que Machado se insere nele. Parece um pouco desguarnecida, no entanto, a outra frente de ataque ao problema do lugar da obra de Machado no sistema literário brasileiro; ou seja, como, já desempenhando uma função canônica, Machado é absorvido pela cultura literária brasileira do século XX.

Os esforços nesse sentido têm sido feitos, principalmente, no âmbito da prosa, em que a figura do Bruxo surge como paradigma incontornável-mostrao a já bastante explorada relação entre São Bernardo, de Graciliano Ramos, e Dom Casmurro, para ficar em um exemplo clássico. ${ }^{2}$ Mas por que se limitaria às suas rubricas de gênero a influência de uma obra em que o signo linguístico é levado à sua plasticidade máxima, em que as fronteiras entre os gêneros são o tempo todo tensionadas? Basta lembrar Capistrano de Abreu: "As Memórias póstumas de Brás Cubas serão um romance?"3 Se também na poesia posterior a 1908 for possível perceber a presença machadiana, a obra poética de Carlos Drummond de Andrade se revelará particularmente impregnada por essa presença. Mas para o poeta - diferentemente do que seria para um prosadorMachado parece representar menos um precursor absoluto, totêmico, o apophrades de Harold Bloom, do que uma "lembrança circular," uma "memória involuntária" ou a mathesis descrita por Roland Barthes em O prazer do texto.

A seguir, buscaremos flagrar essa presença, localizando-a em quatro camadas de absorção do texto machadiano pelo texto drummondiano, ou quatro frentes de diálogo entre as duas obras. A primeira é a da profissão de fé, da peça em que Drummond explicita a eleição de Machado como seu interlocutor e dá forma à persona do "seu" Machado. A segunda é a da identificação poéticoexistencial, ou seja, de uma concepção de mundo compartilhada pelos dois escritores, que ganha corpo em uma correspondente concepção estética. A terceira é a do que chamamos de "retomada de paradigmas"- em outras palavras, da reverberação, na poética drummondiana, de imagens, temas e técnicas da ficção machadiana. A quarta, por fim, é a da "retomada de sintagmas," ou seja, da incorporação, por parte do itabirano, de citações literais da obra do carioca ou de referências diretas a ela.

\footnotetext{
${ }^{2}$ Ver, entre outros, Zilberman.

${ }^{3}$ Em artigo publicado na Gazeta de Notícias do Rio de Janeiro em 30 Janeiro de 1881. Ver Guimarães, Os leitores.
} 


\section{Profissão de fé}

Embora toda a lírica drummondiana tenha fortes traços subjetivistas $\mathrm{e}$ autorreferenciais, A vida passada a limpo (1959) é o livro que assume como projeto a revisão da trajetória do seu eu-poético. É aí que vem publicado "A um Bruxo, com amor," em certa medida poema encomiástico e em certa medida arte poética, em que o poeta requisita Machado como interlocutor que "revolve [nele] tantos enigmas" (Reunião 239). Enquanto a primeira parte do título do poema ("A um Bruxo") explicita o aspecto encomiástico, a segunda ("com amor") indicia a vontade de aproximação, considerando-se que o amor é, já em sua etimologia, uma inclinação, um movimento em direção a algo (Agamben). "A um Bruxo, com amor" equivale, portanto, a "Sobre Machado de Assis, em sua direção."

O poema é composto, em grande parte, por citações literais de trechos da obra machadiana ou referências explícitas a ela, que Drummond costura como se tecesse uma colcha de retalhos - para a qual Machado fornece o pano, a linha e a agulha, uma vez que mesmo nos trechos de lavra própria o poeta se vale de um léxico e de uma dicção que emulam o léxico e a dicção machadianos. Ao prestar uma homenagem a Machado através de um corte-e-colagem da obra do próprio Machado, dando-lhe voz, Drummond parece, de alguma maneira, lidar com um valor estético ideal, que só pode ser atingido de forma mediada por suas fulgurações na realidade. E também reforça, assim, o que propõe Blanchot: que "falar sobre" é "falar com" (183). Acompanhemos, passo a passo e de "mãos dadas," o poeta em sua visita ao prosador.

Em certa casa da Rua Cosme Velho

(que se abre no vazio)

venho visitar-te; e me recebes

na sala trastejada com simplicidade

onde pensamentos ido e vividos

perdem o amarelo

de novo interrogando o céu e a noite. (Reunião 237)

Delineia-se, logo na primeira estrofe, a cena do poema: personagens, local, tempo e ação. Tamanha é a intimidade entre os dois companheiros de ofício, de tal 
maneira a obra de Machado é para Drummond uma entidade viva, que se personifica, ganha forma de gente, e o corpo que o poeta escolhe para lhe dar é o do próprio homem Machado de Assis. Ao longo do poema, homem e obra formam uma entidade compósita e permeável, permitindo ao eu-lírico aludir à obra para tratar do homem ou se dirigir ao homem para abordar a obra. É essa identificação da obra com o homem e a eleição desse homem como interlocutor do poema que tornam possível, por exemplo, a indicação denotativa do movimento de aproximação poética como um deslocamento espacial ("venho visitar-te") e a referência biográfica à "casa da Rua Cosme Velho." Todavia, a casa que "se abre no vazio" opera tanto no registro biográfico, uma vez que o chalé do Cosme Velho fora demolido na década de 1930, quanto no registro literário, reconhecendo a imaterialidade do solo em que tal visita se dá.

Do mesmo modo, a menção aos "pensamentos idos e vividos" é a um só tempo citação da obra e alusão ao homem: por um lado, reproduz o fecho do poema "A Carolina," que figura como dedicatória no volume Relíquias de casa velha: "Que eu, se tenho nos olhos malferidos / Pensamentos de vida formulados / São pensamentos idos e vividos." Por outro, remete também àquilo que motivou a composição do poema: a morte factual da companheira do escritor. É interessante notar que o Machado de Assis figurado por Drummond é um Machado de Assis bastante específico: discreto, recolhido ao Cosme Velho, assolado pela viuvez - se não casmurro e cético, como o velho Bento, com saudade de si mesmo, como o velho Aguiar. De qualquer modo, uma figura outonal do escritor, um homem visto pelas lentes da sua obra (e, mais especialmente, de sua obra final).

O verso "na sala trastejada com simplicidade" recupera um item lexical (o verbo trastejar) já de sabor arcaico na década de 1950 (momento de composição do poema), porém caro ao vocabulário machadiano, conforme se verifica, entre outros lugares, em Quincas Borba: "[Dona Fernanda] foi a bordo recebê-los, conduziu-os à Tijuca, onde um velho amigo da família de Carlos Maria alugara e trastejara uma casa, por ordem dele." 4 Por sua vez, o verso "de novo interrogando o céu e a noite" encerra a estrofe com um movimento que afirma,

\footnotetext{
${ }^{4}$ Todas as citações pertencentes à obra ficcional de Machado de Assis foram retiradas da edição eletrônica dos Romances e contos em hipertexto, preparada por Marta de Senna e disponível digitalmente. Daí não ser feita referência a número de página.
} 
em meio a um cenário amarelecido (como uma antiga fotografia), a potência vivificante da obra do autor, e que tem raízes no conto "Um homem célebre," de Várias histórias. Diz o conto: "A moça dormia ao som da polca, ouvida de cor, enquanto o autor desta não cuidava nem da polca nem da moça, mas das velhas obras clássicas, interrogando o céu e a noite, rogando aos anjos, em último caso ao diabo." No patchwork drummondiano, a angústia criativa do músico Pestana, que é quem interroga o céu e a noite, no contexto original, seu descontentamento consigo mesmo e com os homens, transforma-se em perquirição potente, que espana a poeira de velhos pensamentos; e, no novo contexto, o gesto da personagem se transforma no gesto do seu autor, gesto de confronto desiludido face ao desamparo da natureza, apreendido da leitura dos moralistas. ${ }^{5}$ Passemos à segunda estrofe:

Outros leram da vida um capítulo, tu leste o livro inteiro

Daí esse cansaço nos gestos e, filtrada, uma luz que não vem de parte alguma

pois todos os castiçais

estão apagados. (Reunião 237)

No primeiro verso, a imagem do livro como metáfora da vida remonta à "teoria das edições humanas," formulada no capítulo 27 e demonstrada no capítulo 38 das Memórias póstumas de Brás Cubas. À maneira do Bruxo, um verso quase galhofeiro é seguido por outro de travo melancólico, "Daí esse cansaço nos gestos," possivelmente inspirado no fecho de "O velho Senado," crônica incluída em Páginas recolhidas, que diz: "Alguém ainda quis obstar à ação do porteiro, mas tinha o gesto tão cansado e vagaroso que não alcançou nada" (Páginas recolhidas 178). O quadro que se delineia com a justaposição dos dois versoscom as alusões à "teoria das edições humanas" das Memórias póstumas e à

\footnotetext{
${ }^{5}$ Em sua leitura de "A máquina do mundo," Alfredo Bosi captura esse mesmo gesto, perpetrado pelo eu-lírico drummondiano: "Nessa altura, a máquina 'fala,' mas sintomaticamente sem voz. A sua convocação é muda, não passa pelas rotas da intersubjetividade: um diálogo de impossíveis, pois nem a Coisa emite som algum, nem ao convidado 'noturno e miserável' é dado responder. . . . Em Drummond, a percepção do intervalo entre a máquina do mundo e o seu espectador é tão aguda que só o silêncio pode significá-la." (111-12).
} 
lassidão reinante por ocasião do fechamento do velho Senado (tanto da parte do "cansado e vagaroso" porteiro quanto daquele que apenas "quis" lhe obstar a ação) - é de desilusão com a "leitura da vida"; dístico que bem poderia se intitular "Das negativas." Nos três versos seguintes, entretanto, o eu-poético drummondiano parece trair o espírito da letra machadiana na apropriação que faz de algo que, no conto "Entre santos," de Várias histórias, é apenas uma retórica mística, utilizada em chave paródica com o objetivo de denunciar o mundanismo da personagem Sales, para sugerir um real bálsamo face a tal desilusão, por meio do transcendente: "Mas, se tudo isso era espantoso, não menos o era a luz, que não vinha de parte nenhuma, porque os lustres e castiçais estavam todos apagados."

Veja-se, agora, a terceira estrofe, em que o eu-poético drummondiano vai iluminando alternativamente as diversas faces do narrador machadiano:

Contas a meia voz

maneiras de amar e de compor ministérios

e deitá-los abaixo, entre malinas

e bruxelas.

Conheces a fundo

a geologia moral dos Lobos Neves

e essa espécie de olhos derramados que não foram feitos para ciumentos.

E ficas mirando o ratinho meio cadáver com a polida, minuciosa curiosidade de quem saboreia por tabela o prazer de Fortunato, vivisseccionista amador.

Olhas para a guerra, o murro, a facada como para uma simples quebra da monotonia universal e tens no rosto antigo uma expressão a que não acho nome certo (das sensações do mundo a mais sutil): volúpia do aborrecimento? ou, grande lascivo, do nada? (Reunião 237-8) 
Nos quatro primeiros versos, a estrofe traça o desenho de alguém que contempla a volubilidade, as mudanças incessantes que se dão no mundo dos fenômenos; para tanto, faz uso do conto "Primas de Sapucaia," de Histórias sem data: "E durante esse tempo, a Ocasião passa, vagarosa, cabisbaixa, apoiando-se no chapelinho de sol: passa, dobra a esquina, e adeus ... O ministério esfacelavase; malinas e bruxelas; nisi lege sine moribus." Esse mesmo alguém que contempla a volubilidade perscruta igualmente a solidez, nos quatro versos seguintes, ao demonstrar conhecer a "geologia moral dos Lobos Neves," decalcada do capítulo 87 das Memórias póstumas, no qual o narradorpersonagem reconhece o caráter e a resiliência de seu patético antagonista; e conhecer também os "olhos derramados que não foram feitos para homens ciumentos," retirados de "A desejada das gentes," conto de Várias histórias, que se funda na peremptoriedade do despotismo afetivo.

Os quatro versos seguintes continuam o retrato de uma persona observadora, então por meio da reencenação do momento fulcral de "A causa secreta," conto também de Várias histórias, em que o próprio narrador e o leitor são implicados em um jogo de desejos perversos e espreitas comprometedoras. O retrato se encerra com uma sucessão de imagens retiradas de Memórias póstumas: os versos "Olhas para a guerra, o murro, a facada / como para uma simples quebra da monotonia universal" têm origem no capítulo 117, onde se lê:

Reorganizada a sociedade pelo método dele, nem por isso ficavam eliminadas a guerra, a insurreição, o simples murro, a facada anônima, a miséria, a fome, as doenças; mas sendo esses supostos flagelos verdadeiros equívocos do entendimento, porque não passariam de movimentos externos da substância interior, destinados a não influir sobre o homem, senão como simples quebra da monotonia universal, claro estava que a sua existência não impediria a felicidade humana.

Já o dístico final combina elementos dos capítulos 7 e 42 do romance machadiano de 1881: "Grande lascivo, espera-te a voluptuosidade do nada"; "e eis aí como, pela simples transmissão de uma força, se tocam os extremos sociais, e se estabelece uma cousa que poderemos chamar solidariedade do aborrecimento humano." Para recompor, sintetizadas, essas faces do narrador machadiano, o poeta não remonta apenas aos seus atos factuais, mas também aos seus atos 
elocutórios, através de uma modalização da forma de introduzi-las: "Contas a meia voz," para o observador da transitoriedade; "Conheces a fundo," para o investigador da solidez; "Ficas mirando," para o que bisbilhota a perversidade; "Olhas" e "tens no rosto," para aquele que testemunha o confronto entre sujeito e mundo. Vertiginoso caleidoscópio, em que as imagens criadas por Machado giram, desdobram-se, recombinam-se e se condensam. Voltemos os olhos, por um momento, para a quarta estrofe:

O vento que rola do Silvestre leva o diálogo, e o mesmo som do relógio, lento, igual e seco, tal um pigarro que parece vir do tempo da Stoltz e do gabinete Paraná, mostra que os homens morreram.

A terra está nua deles.

Contudo, em longe recanto, a ramagem começa a sussurrar alguma coisa que não se entende logo e parece a canção das manhãs novas.

Bem a distingo, ronda clara:

é Flora, com olhos dotados de um mover particular entre mavioso e pensativo.

Marcela, a rir com expressão cândida (e outra coisa);

Virgília, cujos olhos dão a sensação singular de luz úmida;

Mariana, que os tem redondos e namorados e Sancha, de olhos intimativos;

e os grandes, de Capitu, abertos como a vaga do mar lá fora, o mar que fala a mesma linguagem

obscura e nova de D. Severina e das chinelinhas de alcova de Conceição.

A todas decifraste íris e braços

e delas disseste a razão última e refolhada

moça, flor mulher flor

canção de manhã nova...

E ao pé dessa música dissimulas (ou insinuas, quem sabe) 
o turvo grunhir dos porcos, troça concentrada e filosófica

entre loucos que riem de ser louco

e os que vão à Rua da Misericórdia e não a encontram. (Reunião 238)

Seria exaustivo indicar e comentar aqui, uma a uma, a origem de todos os excertos machadianos que compõem a estrofe. Deixe-se anotada, no entanto, a abundância de citações tomadas de empréstimo às narrativas curtas de Várias histórias: "o mesmo som do relógio, lento, igual e seco" vem do conto "O enfermeiro"; o "pigarro que parece vir do tempo da Stoltz ou do gabinete Paraná" foi recortado do conto "D. Paula"; "mostra que os homens morreram," do conto "Viver!"; "Mariana, que os tem redondos e namorados," do conto "Mariana"; e "o mar que fala a mesma linguagem / obscura e nova de D. Severina," do conto "Uns braços." Ainda no âmbito do conto, sublinhe-se a menção às "chinelinhas de alcova de Conceição," protagonista de "Missa do galo," de Páginas recolhidas; e àqueles "que vão à rua da Misericórdia" em busca de algo que não encontram, tema de "O rei dos caiporas," narrativa curta veiculada em periódico, que não foi republicada por Machado em volume, sendo-o postumamente em Contos avulsos. Também a poesia de Machado tem seu discreto lugar, no verso "moça, flor mulher flor," em que se ouve o eco de "Menina e moça," poema de Falenas.

Drummond monta, nessa estrofe, uma galeria com algumas das principais personagens femininas de Machado. Além das já indicadas, que pertencem aos contos, assinale-se a presença daquelas que habitam o universo dos romances, cada uma delas descrita com as precisas palavras utilizadas pelo Bruxo. Os "olhos dotados de um mover particular" de Flora estão no capítulo 31 de Esaú e Jacó; a "expressão cândida (e outra coisa)" de Marcela está no capítulo 15 de Memórias póstumas; ainda neste romance, os "olhos que dão a sensação singular de luz úmida" de Virgília constam no capítulo 63; os "olhos intimativos" de Sancha ficam ditos no capítulo 118 de Dom Casmurro, livro de que também é retirada, do capítulo 123, a descrição de Capitu. Ao recorte feito por Drummond dos traços mais marcantes das mulheres machadianas subjaz a compreensão de que o erotismo, na ficção de Machado de Assis, é metonímico-elege partes em que se adivinha o todo. Revela-o não apenas a descrição das personagens por meio dos seus olhos, sorrisos, braços e até chinelinhas, como também a conclusão a que o poeta chega a respeito do procedimento do prosador em relação a elas: 
"a todas decifraste íris e braços / e delas disseste a razão última e refolhada." Sigamos para a próxima estrofe, a quinta:

O eflúvio da manhã, quem o pede ao crepúsculo da tarde?

Uma presença, o clarineta,

vai pé ante pé procurar o remédio, mas haverá remédio para existir senão existir?

E, para os dias mais ásperos, além da cocaína moral dos bons livros?

Que crime cometemos além de viver e porventura amar não se sabe a quem, mas amar? (Reunião 238)

Aproximando-se do fim, o poema faz nova inflexão melancólica, reflete sobre a fuga inexorável do tempo, sobre o sentido e as distrações da existência. Para tanto, põe lado a lado citações de alguns dos trechos mais sombrios, não obstante resignados, da ficção machadiana. Os dois primeiros versos são transpostos ipsis litteris do capítulo 115 das Memórias póstumas, em que se lê:

Eles lá iam, mar em fora, no espaço e no tempo, e eu ficava-me ali numa ponta de mesa, com os meus quarenta e tantos anos, tão vadios e tão vazios; ficava-me para os não ver nunca mais, porque ela poderia tornar e tornou, mas o eflúvio da manhã, quem é que o pediu ao crepúsculo da tarde?

Os quatro versos posteriores a esses remontam ao amargo fecho de "Um homem célebre," ao veneno-remédio que é a música para o frustrado Pestana; a referência à "cocaína moral dos bons livros" está em Dom Casmurro, capítulo 136; e o crime de viver e porventura amar alude ao capítulo 107 de Esaú e Jacó, em que se lê: "Quem morreu, morreu. Era o caso de Flora; mas que crime teria cometido aquela moça, além do de viver, e porventura o de amar, não se sabe a quem, mas amar?" 
Após largo passeio pelos temas da ficção machadiana, a sexta estrofe volta a se dirigir a um interlocutor imaginário, ao homem-obra Machado de Assis, pela primeira vez claramente nomeado, por meio de seu célebre epíteto-_"Bruxo":

Todos os cemitérios se parecem,

e não pousas em nenhum deles, mas onde a dúvida

apalpa o mármore da verdade, a descobrir

a fenda necessária;

onde o diabo joga dama com o destino, estás sempre aí, bruxo alusivo e zombeteiro, que revolves em mim tantos enigmas. (Reunião 238-39)

Talvez por aí a presença do homem se fazer mais intensa, a requisição da obra se torna mais parcimoniosa, tendo sido identificadas apenas duas referências. No primeiro verso, novo saque ao parágrafo final de "O velho Senado": "Se valesse a pena saber o nome do cemitério, iria eu catá-lo, mas não vale; todos os cemitérios se parecem" (Páginas recolhidas 178). E, no verso "onde o diabo joga dama com o destino," uma remissão difusa aos diversos momentos em que Machado encena as artimanhas do diabo - o conto "A igreja do diabo" de Histórias sem data; o capítulo 9 de Dom Casmurro; e o capítulo 13 de Esaú e Jacó.

É interessante, para o cultor das obras de Machado de Assis e Carlos Drummond de Andrade em princípios do século XXI, perceber como o visgo corrosivo da narrativa machadiana, a desconstrução de todas as certezas por ela promovida, ganha forma na poética drummondiana através da imagem "[d]a dúvida / [que] apalpa o mármore da verdade, a descobrir / a fenda necessária," tão próxima à desenvolvida, dentro do discurso da crítica machadiana, por Alfredo Bosi-a da dúvida que cinde a máscara da verdade, a criar a necessária fenda (Bosi 2007). Examinemos, finalmente, a última estrofe:

Um som remoto e brando

rompe em meio a embriões e ruínas, eternas exéquias e aleluias eternas, e chega ao despistamento de teu pencenê.

O estribeiro Oblivion 
bate à porta e chama ao espetáculo

promovido para divertir o planeta Saturno.

Dás a volta à chave,

envolves-te na capa,

e qual novo Ariel, sem mais resposta, sais pela janela, dissolves-te no ar. (Reunião 239)

Os três versos iniciais formam um mosaico de citações que têm origem, todas, no livro Várias histórias. A expressão "um som remoto e brando" encontra-se no conto "D. Paula," já citado em uma das estrofes anteriores; a formulação de que algo "rompe em meio a embriões e ruínas" consta em "O cônego ou Metafísica do estilo"; e as "eternas exéquias e aleluias eternas," no conto "Viver!." Sob diferentes prismas, os versos debruçam-se sobre a experiência da passagem do tempo, motivo pelo qual culminam com a conclamação, logo a seguir, do estribeiro Oblivion, objeto do capítulo 135 das Memórias póstumas. Os versos finais do poema fazem eco, mais uma vez, ao fecho da crônica "O velho Senado": "Alguém ainda quis obstar à ação do porteiro, mas tinha o gesto tão cansado e vagaroso que não alcançou nada; aquele deu volta à chave, envolveu-se na capa, saiu por uma das janelas e esvaiu-se no ar, a caminho de algum cemitério, provavelmente" (Páginas recolhidas 178). A imagem de suave dissolução é reforçada pela menção a Ariel, espírito aéreo de A tempestade, de Shakespeare, citado pelo narrador machadiano no capítulo 82 de Quincas Borba: "Que misterioso Próspero transformava assim uma ilha banal em mascarada sublime? 'Vai, Ariel, traze aqui os teus companheiros, para que eu mostre a este jovem casal alguns feitiços da minha feitiçaria."

$\mathrm{O}$ inventário das referências à obra de Machado de Assis encontradas no poema "A um Bruxo, com amor," de Carlos Drummond de Andrade, permite reconstituir o perfil da persona literária do prosador criada pelo poeta. São citados apenas os romances e livros de contos escritos entre 1881 e 1906; excluem-se, assim, os romances e livros de contos iniciais (Ressurreição, A mão e a luva, Helena, Iaiá Garcia, Contos fluminenses e Contos da meia-noite), bem como a obra derradeira, o Memorial de Aires. O romance que Drummond requisita com maior frequência é Memórias póstumas de Brás Cubas (1881), seguido por Dom Casmurro (1900), Esaú e Jacó (1904) e Quincas Borba (1891); já o livro de contos convocado mais amiúde é Várias histórias (1896), a que se 
seguem Histórias sem data (1884) Páginas recolhidas (1899) e Relíquias de casa velha (1906).

É digno de nota o fato de os contos "Um homem célebre," "D. Paula" e "Viver!," todos de Várias histórias, serem citados, cada um deles, duas vezes no poema, ao contrário dos demais contos aos quais é feita alusão, que o são uma única vez. Observe-se, ainda, que a crônica "O velho Senado," de Páginas recolhidas, única representante do seu gênero presente no poema, é convocada três vezes, em três passagens centrais de "A um bruxo, com amor"-em seu fecho, inclusive. "O velho Senado" parece funcionar como clave que dá o tom do poema, pela razão mesma de a constituição da sua instância narrativa ir ao encontro da persona "Machado de Assis" criada por Drummond: na crônica machadiana como no poema drummondiano, os aspectos biográfico e literário permeiam-se, os registros histórico e ficcional mesclam-se.

Em meio ao oceano que é a obra de Machado de Assis, ao moldar para si uma imagem particular do escritor, ao indicar o repertório específico com que lida, ao destacar certos procedimentos narrativos de Machado, como a alusão e a zombaria, e ao enfatizar a constituição de uma voz compósita e permeável, Drummond tem como resultado a criação de seu próprio precursor. Ao emular, em seu discurso, o discurso desse precursor, identifica-se com ele; e, ao incluir a sua própria imagem literária na emulação do discurso do precursor, cria uma relação especular cruzada, em um gesto de filiação.

\section{Identificação poético-existencial}

No contexto da literatura produzida no Brasil, Machado de Assis assoma como o precursor das grandes questões poético-existenciais que subjazem à poesia de Carlos Drummond de Andrade e nela se atualizam. Os dois autores compartilham a tal ponto a visão de um mundo desencantado, a desconfiança em relação ao homem e à sociedade e o vislumbre de uma única via de escape na linguagem, que seria possível permutar alguns dos termos com os quais a crítica caracterizou um e outro. Façamos, então, o exercício de flagrar o "princípio-corrosão," a "poética da dissipação" e o mecanismo "palavra puxa palavra," originalmente concebidos para descrever a poética drummondiana, em Machado; e a constituição de um "homem subterrâneo" e as estratégias de "humour," reiteradamente identificadas na narrativa machadiana, em Drummond. 
Luiz Costa Lima identifica na poética drummondiana um "princípiocorrosão," que expressa uma percepção desoladora da passagem do tempo, especialmente quando esta se corporifica em objetos portadores de memória. Segundo tal princípio, o tempo atuaria sobre objetos e memórias como um ácido, corroendo de fora para dentro, até chegar a um núcleo duro de opacidade e desencanto, a experiência de que eles são portadores. O poema "Carta," de Lição de coisas, oferece um dos exemplos mais pungentes do princípio-corrosão em pleno funcionamento; nele, o eu-poético que volta seu olhar sobre o passado verifica não apenas a perda irreparável de pessoas queridas, mas a perda mais irreparável ainda de aspectos de si mesmo:

Há muito tempo, sim, que não te escrevo.

Ficaram velhas todas as notícias.

Eu mesmo envelheci: Olha, em relevo, estes sinais em mim, não das carícias

(tão leves) que fazias no meu rosto:

são golpes, são espinhos, são lembranças

da vida a teu menino, que ao sol-posto

perde a sabedoria das crianças.

A falta que me fazes não é tanto

à hora de dormir, quando dizias

"Deus te abençoe," e a noite abria em sonho.

É quando, ao despertar, revejo a um canto

a noite acumulada de meus dias,

e sinto que estou vivo, e que não sonho. (Reunião 270)

Não parece ser outro o princípio que anima a voz narrativa machadiana em passos como, entre outros, o do capítulo 2 de Dom Casmurro: "Em tudo, se o rosto é igual, a fisionomia é diferente. Se só me faltassem os outros, vá; um homem consola-se mais ou menos das pessoas que perde; mas falto eu mesmo, e esta lacuna é tudo." Em ambos os casos, trata-se de uma mirada retrospectiva e reflexiva de um sujeito maduro sobre o seu passado; e além de certo 
desdobramento natural da distância temporal em distância espacial, fazendo com que ele tenha dificuldade em reconhecer com nitidez os seus próprios contornos na juventude, há também uma erosão qualitativa desses mesmos contornos, fruto do seu processo particular de amadurecimento.

Por sua vez, José Guilherme Merquior, com base nas reflexões de Blanchot a partir de Bataille, identifica em Drummond uma "poética da dissipação": seu projeto poético não busca capturar um instante e fixá-lo através da escrita, nem sequer celebrar as experiências acontecidas, mas sim vivenciar a impermanência, a dissolução. O texto é, assim, emanação de um sujeito que se expande, que se derrama para fora de si e cuja riqueza consiste justamente na pujança do seu desperdício. A reconstrução de sua trajetória se faz, então, por meio da recolha desses fragmentos de experiência, disseminados ou simplesmente vislumbrados ao longo do discurso. Conforme registram os dois quartetos finais de "Ontem" (A rosa do povo): "Tudo foi breve / e definitivo. / Eis está gravado // não no ar, em mim, que por minha vez, escrevo, dissipo" (Reunião 92). Não há nessa voz algo semelhante àquela que escreve para matar o tempo-na eternidade (Memórias póstumas) ou, pelo menos, na barca para Petrópolis (Esaú e Jacó)? Não anima esta voz um mesmo sentimento íntimo que anima aquela outra, que, desde a velhice, olha para a sua juventude e constata: "Entre luz e fusco, tudo há de ser breve como esse instante" (Dom Casmurro)? Talvez afinem-se essas duas vozes justamente naquilo que têm de deliberadamente quebradiças, como ruínas que realizassem a arqueologia de si mesmas.

Othon Moacyr Garcia, por seu turno, chamou de "palavra puxa palavra" o jogo estrutural explorado amplamente por Drummond, no qual uma associação formal entre palavras enseja uma associação-seja por semelhança ou por oposição - também entre os seus significados. O jogo, que grassa por toda a lírica drummondiana, está presente já no "Poema de sete faces," de Alguma poesia, em que é justamente a falta de correspondência entre "mundo" e "Raimundo" que denuncia a falta de solução para o dilema entre o coração e o "vasto mundo":

Mundo mundo vasto mundo

se eu me chamasse Raimundo

seria uma rima, não uma solução.

Mundo mundo vasto mundo, mais vasto é meu coração. (Reunião 3) 
E esse recurso estrutural torna-se ainda mais produtivo em peças como " $\mathrm{O}$ amor bate na aorta," de Brejo das almas, em que a aproximação entre as palavras "porta," "aorta" e "horta," de caráter eminentemente formal, promove a aproximação dos campos semânticos por elas mobilizados:

$\mathrm{O}$ amor bate na porta

o amor bate na aorta,

fui abrir e me constipei.

Cardíaco e melancólico,

o amor ronca na horta

entre pés de laranjeira

entre uvas meio verdes

e desejos já maduros. (Reunião 33)

Descontadas as devidas diferenças de gênero, tal procedimento também se verifica na prosa de Machado de Assis. Afinal, o encadeamento narrativo entre os capítulos 23 e 24 das Memórias póstumas não se realiza com o auxílio do jogo de palavras dos títulos dos capítulos - "Triste, mas curto," "Curto, mas alegre"? E o despotismo classista de Brás em relação à "Flor da moita" também não ganha sua expressão máxima no quiasmo presente no capítulo 33- "Por que bonita, se coxa? Por que coxa, se bonita?"-, escondendo-se atrás da aparente superficialidade de um jogo de palavras? E como uma última exemplificação, tirada sempre do romance de 1881: não é a partir da repetição desleixada, sobre uma folha de papel, do verso "arma virunque cano," que no capítulo 26 o narrador-personagem chega a nome "Virgílio" e que seu pai chega a "Virgília"?

$\mathrm{Na}$ permutação de jargões das críticas drummondiana e machadiana aqui proposta, o caminho inverso também funciona. Augusto Meyer foi quem primeiro trouxe para o meio literário brasileiro a expressão "homem subterrâneo," utilizada por Dostoiévski para referir-se a uma de suas mais representativas personagens, aplicando-a à voz narrativa de Machado de Assis. Tal expressão faz referência aos recôncavos da consciência humana, seus sótãos, porões e desvãos, seu inconsciente e as contradições e afetividades ali latentes, os quais certos autores - entre os quais, o russo e o brasileiro-logram trazer à tona, por meio de de suas personagens em primeira pessoa. 
"Homens subterrâneos" são, entre outras personagens de Machado de Assis, Brás Cubas, quando professa sua mesquinhez e leviandade, seus prazeres perversos e sua descrença, e Bento Santiago, quando confessa seus desejos de morte (da mãe, do suposto filho, de si mesmo), sua obsessão e vileza. Esse tipo de autodesnudamento da voz narrativa (ainda que ela traga em si, dissimuladas, estratégias de manipulação de sua recepção), sempre em cores sombrias, que Dostoiévski e Machado realizam em prosa, Drummond não o realiza em verso, em poemas como "Sentimento do mundo," do livro homônimo?

Tenho apenas duas mãos

e o sentimento do mundo, mas estou cheio de escravos, minhas lembranças escorrem e o corpo transige na confluência do amor.

Quando me levantar, o céu estará morto e saqueado, eu mesmo estarei morto, morto meu desejo, morto o pântano sem acordes.

$[\ldots]$

Quando os corpos passarem, eu ficarei sozinho desfiando a recordação do sineiro, da viúva e do microscopista que habitavam a barraca e não foram encontrados ao amanhecer

esse amanhecer mais noite que a noite. (Reunião 45) 
Ou então em "Os ombros suportam o mundo," do mesmo livro, entre tantos outros, em que têm vazão o "instante de febre / [a] gula e jejum" (expressões de "José") de um homem igualmente subterrâneo (Reunião 70)?

Outro conceito-chave da crítica machadiana, introduzido ainda no início do século XX por Alcides Maya, é o de "humour," tomado de empréstimo à crítica sterniana e entendido como um "bálsamo que um espírito generoso esparge sobre os males da vida" (Maya 16), uma consciência individual atenta, que observa a precariedade humana e a converte em um saboroso jogo de linguagem. Pense-se, por exemplo, no continho que o narrador de Quincas Borba declara ter ouvido quando criança do padre Chagas, em que um ébrio pede licença a uma senhora para acender o seu charuto na chama que consome a casa dela. A desfaçatez do ébrio e a desfaçatez maior ainda do narrador - que lhe louva o respeito ao princípio de propriedade - face à miséria alheia parecem repontar no "Consolo na praia" de $A$ rosa do povo (no qual, aliás, em um exercício de autoconsciência escritural plena, é feita referência ao próprio conceito de humour):

Vamos, não chores...

A infância está perdida.

A mocidade está perdida.

Mas a vida não se perdeu.

O primeiro amor passou.

O segundo amor passou.

O terceiro amor passou.

Mas o coração continua.

Perdeste o melhor amigo.

Não tentaste qualquer viagem.

Não possuis casa, navio, terra.

Mas tens um cão.

Algumas palavras duras, em voz mansa, te golpearam.

Nunca, nunca cicatrizam.

Mas, e o humour? 
A injustiça não se resolve.

À sombra do mundo errado

murmuraste um protesto tímido.

Mas virão outros.

Tudo somado, devias

precipitar-te, de vez, nas águas.

Estás nu na areia, no vento...

Dorme, meu filho. (Reunião 116)

Seria temerário atribuir exclusivamente à influência de Machado o surgimento dessas perspectivas poético-existenciais em Drummond, já que, conforme revelam os estudos que se debruçam sobre a inserção de Machado em certa tradição que perpassa, como um veio subterrâneo, a tradição ocidental, de Luciano de Samósata a Sterne e a John Barth, tal linhagem não se inicia nem se encerra em Machado. Todavia, sendo Machado o elo mais próximo da cadeia, sendo aquele que "passa o bastão" para Drummond, é legítimo considera-lo como o principal mediador dessa tradição e aquele que contamina de maneira mais íntima a poética do itabirano.

\section{Retomada de paradigmas}

Como recuperação de uma imagem, pense-se no capítulo "Que escapou a Aristóteles," de Memórias póstumas, que descreve-utilizando a metáfora de uma cadeia de bolas, em que cada bola recebe um impulso da anterior e o transmite à posterior - como o "piparote do passado" de Marcela se transmitiu a Brás e, deste, a Virgília, que não tinha inicialmente relação alguma com Marcela. Esta dinâmica, que Brás chama de "solidariedade do aborrecimento humano," não é outra, senão a figurada por Drummond na "Quadrilha" de Alguma poesia, em que igualmente tem lugar uma cadeia de personagens em que cada uma recebe da precedente e transmite à seguinte um impulso, originado na primeira da série. E assim como a corrente Marcela-Brás-Virgília, a quadrilha JoãoTeresa-Raimundo-Maria-Joaquim-Lili somente é rompida com a intromissão de um elemento externo e abrupto, que toma de assalto o último integrante- seja 
esse elemento Lobo Neves ou J. Pinto Fernandes, "que não tinha[m] entrado na história" (Reunião 19) até então.

Outra imagem machadiana que parece refletir-se, embora bastante reelaborada, em Drummond, é a da "Fusão, difusão, confusão" “Transfusão, enfim" de Flora, tratada nos capítulos 129 e 130 de Esaú e Jacó. Neles, a propósito da impossível escolha, por parte da moça, entre Pedro e Paulo, o narrador (nesse momento, Aires) declara: "Se eu consultasse o meu gosto, nem os dous rapazes fariam um só mancebo, nem a moça seria uma só donzela. Corrigiria a natureza desdobrando Flora.” Ao passo em que nas alucinações da infeliz filha de D. Cláudia são os gêmeos que se fundem em uma única pessoa, no desejo do narrador - desejo interdito, contudo fundamental na armação da cena - é ela que se desdobra para poder atender a ambos os irmãos (e, talvez, ainda ao narrador-espectador, uma vez que ele não especifica que o desdobramento proposto é apenas uma bipartição). Como que acatando a sugestão do conselheiro, Drummond realiza o "Desdobramento de Adalgisa" em Brejo das almas. Enquanto o nome da personagem rende homenagem à musa modernista Adalgisa Nery, a operação a que ela é submetida retoma aspectos da erótica machadiana, tanto de modo geral (metonímica, fetichista), quanto relativamente ao "caso" Flora, em particular (o delírio, a dissipação):

\begin{abstract}
Alguns mal sabem escolher, outros misturam depressa perna de uma, braço de outra, e o indiviso sexo aspiram, como se as duas fossem uma, quando é uma que são duas.
\end{abstract}

\title{
$[\ldots]$
}

Sou a quádrupla Adalgisa, sou a múltipla, sou a única e analgésica Adalgisa.

Sorvei-me, gastai-me e ide. Para onde quer que vades, o mundo é só Adalgisa. (Reunião 43-44) 
Como exemplo da recuperação de um tema, tenha-se em mente o mergulho vertiginoso de Brás Cubas no abismo dos séculos, durante o seu delírio, em que desfilam à sua frente os mais sublimes e formidáveis mistérios e verdades, e o subsequente refreamento desse mergulho, representado pela segurança do acordar, pela familiaridade do gato doméstico, pelo retorno da Razão a casa. Assim como a Pandora de Machado, "A máquina do mundo" de Drummond (constante em Claro enigma) abre o seu seio para um eu-poético vacilante, que palmilha "vagamente uma estrada ... pedregosa" e que desdenha "colher a coisa oferta." Nas palavras de Costa Lima: “[o] poema, um dos máximos alcances da poética drummondiana e nacional, apresenta, por um artifício semelhante ao de Brás Cubas cavalgando o hipopótamo do delírio, a penetração mais aguda da corrosão até a opacidade . . . Não se trata de postular uma nova concepção da História, mas simplesmente de renunciar a seu esforço compreensivo" (212).

Como exemplo, por fim, da recuperação de uma técnica, observe-se nos dois autores aquilo que Michel Riffaterre chama de "intertextualidade intratextual": a alusão, em determinada obra de determinado autor, a um elemento que consta em outra obra do mesmo autor. Esse procedimento aponta para um processo de escrita que parte da releitura, da revisão, da reelaboração, por parte do autor, daquilo que já havia escrito-processo de escrita, este, que é apontado por Silviano Santiago como característico de Machado de Assis (29-30). As ocorrências textuais mais evidentes desse procedimento talvez sejam intervenções como "se me fizeste o favor de ler as Memórias póstumas de Brás Cubas," feita pelo narrador no quarto capítulo de Quincas Borba, e a ubiquidade do conselheiro Aires, que surge ora como autor, ora como narrador, ora como personagem nos dois romances finais de Machado, Esaú e Jacó e Memorial de Aires. Também na poesia de Drummond esse procedimento é recorrente e estrutural: a pedra "No meio do caminho," de Alguma poesia (1930), é avaliada em "Legado," de Claro enigma (1951): "De tudo quanto foi meu passo caprichoso / na vida restará, pois o resto se esfuma, / uma pedra que havia em meio do caminho" (Reunião 165). O coração mais vasto que o mundo, do "Poema de sete faces," também de Alguma poesia, é desmentido em "Mundo grande," de Sentimento do mundo (1940):

Não, meu coração não é maior que o mundo.

É muito menor. 
Nele não cabem nem as minhas dores.

Por isso gosto tanto de me contar.

Por isso me dispo,

por isso me grito,

por isso frequento os jornais, me exponho cruamente nas livrarias:

preciso de todos. (Reunião 60)

E as "Mãos dadas," igualmente de Sentimento do mundo, são excluídas do mundo de "Mas viveremos," de Rosa do povo (1945): "Já não há mãos dadas no mundo. / Elas agora viajarão sozinhas. / Sem o fogo dos velhos contatos, / Que ardia por dentro e dava coragem" (Reunião 132).

\section{Retomada de sintagmas}

Um caso já clássico de retomada ipsis litteris de trechos da obra machadiana é o do diálogo "—O que é eterno, Iaiá Lindinha? / - Ingrato! É o amor que te tenho," originalmente pertencente ao conto "Eterno!," de Machado (Páginas recolhidas, 1899), e apropriado por Drummond no poema "Eterno" (Fazendeiro do ar, 1953). Outro exemplo, menos difundido, mas já indicado por Marlene de Castro Correia (126-27), é o do lamento do sol- "Por que não nasci eu um simples vagalume?"-, com que se encerra o soneto "Círculo vicioso," escrito por Machado em 1878 (Revista Brasileira, Junho de 1879; Gazeta de Notícias de 2 Janeiro de 1880; e Ocidentais, de Poesia completa, 1901). Drummond perverte o tom quase patético do poema machadiano e em seu "Noite na repartição," de Rosa do povo (1945), faz com que - durante a conversa noturna na repartição, entre os objetos animados e inanimados que ali habitam — a sarcástica aranha diga à queixosa porta: "Chega! / Espero que não me queiras nascer um simples vaga-lume" (Reunião 109).

Para encerrar este provisório mapeamento dos vasos comunicantes entre Machado e Drummond aqui delineado, vejamos um último caso de referência direta do poeta ao prosador, que parece ter passado desapercebido pela crítica. No capítulo 11 de Ressurreição (1872), Machado faz Félix—seu pusilânime protagonista, aprendiz de Dom Casmurro - dizer a Lívia, a heroína da trama: "Fizeste brotar dentre as ruínas uma flor solitária, mas bela; única neste árido terreno do meu coração." Muitos anos depois, em "Entre santos," conto de Várias 
histórias (1896), o escritor põe na boca de São Francisco de Sales o seguinte juízo a respeito da personagem Sales, um sovina incorrigível que vinha lhe oferecer seu tão querido dinheiro, em troca da recuperação da saúde da mulher: "naquele muro aspérrimo brotou uma flor descorada e sem cheiro, mas uma flor." É improvável que Drummond não tivesse no fundo-ou talvez não tão no fundo - de sua memória essas duas belas peças de prosa machadiana, quando compôs uma de suas obras-primas, "A flor e a náusea," de A rosa do povo (1945), em que se pode quase ouvi-las, apenas retrabalhadas:

Passem de longe bondes, ônibus, rio de aço do tráfego.

Uma flor ainda desbotada

ilude a polícia, rompe o asfalto.

Façam completo silêncio, paralisem os negócios, garanto que uma flor nasceu.

Sua cor não se percebe.

Suas pétalas não se abrem.

Seu nome não está nos livros.

É feia, mas é realmente uma flor.

Sento-me no chão da capital do país às cinco horas da tarde e lentamente passo a mão nessa forma insegura.

Do lado das montanhas, nuvens maciças avolumam-se.

Pequenos pontos brancos movem-se no mar, galinhas em pânico.

É feia. Mas é uma flor. Furou o asfalto, o tédio, o nojo e o ódio. (Reunião 78-9)

\section{Conclusão}

No palimpsesto drummondiano, muitas outras dessas "conversações do papel e para o papel"6 há para serem ouvidas, dando a ver um poeta-leitor cada vez mais sofisticado. Conversações literárias e, literalmente, do papel para o papel, pois o mesmo "antigo papel chamado de peso, marca Bath," ao qual o conselheiro Aires

\footnotetext{
${ }^{6}$ A expressão é utilizada por Aires em seu Memorial, na entrada de 24 de Maio de 1888.
} 
faz referência na entrada de 30 Junho de 1888 do Memorial (note-se: trata-se do único papel disponível na fazenda do barão de Santa-Pia, onde Fidélia fora liquidar os negócios do pai, recém-falecido), é referido pelo eu-lírico de "Os bens e o sangue," de Claro enigma-poema drummondiano que, por excelência, encena o acerto de contas familiar: "Por isto neste papel azul Bath escrevemos com a nossa melhor letra / Este nomes $q$ em qualquer tempo desafiarão tramoia, trapaça e treta" (Reunião 186).

Dos diálogos propostos, destaquem-se aqui, à guisa de conclusão, dois pontos principais. O primeiro é que a leitura da obra de Machado de Assis por parte de Carlos Drummond de Andrade é abrangente e atenta, sendo possível rastrear na poesia do autor mineiro traços do romance, do conto e da poesia do escritor fluminense. E o segundo é que, à luz das solicitações feitas por Drummond, a obra de Machado revela-se ainda mais à frente de seu tempo. A posição constante de suspeição em que coloca o sujeito, o rompimento profundo com certa subjetivismo patético e o alto grau de autoconsciência metaliterária, valores que seriam pontos de pauta dos diversos Modernismos, século XX afora, fora e dentro do Brasil, já estão presentes na estética machadiana — demandando de teóricos, historiógrafos e críticos uma compreensão mais em continuum, menos por rupturas do que por negociações, da história da literatura.

Como uma espécie de coda ao exame exclusivamente literário que teve lugar neste ensaio- que buscou flagrar as ressonâncias de uma obra em outra obra , vale comentar rapidamente as menções mais significativas feitas pelo escritor Carlos Drummond de Andrade ao escritor Machado de Assis. ${ }^{7}$ Em 1925, aos 22 anos e ainda em Belo Horizonte, Drummond publica no número de lançamento de $A$ revista, da qual era um dos editores, a curta peça crítica, de duas páginas apenas e com ares de manifesto, "Sobre a tradição em literatura." Sob a influência do Modernismo iconoclasta de 1922 e de Mário de Andrade, que conhecera no ano anterior (1924), o poeta-crítico encena aí o assassinato simbólico daquele que assumia o lugar de pai na família literária que se criara para si. Nesse texto, ele assume sua filiação a Machado, assim como a necessidade de sacrificá-lo, para poder seguir adiante:

\footnotetext{
${ }^{7}$ Ver, entre outros, Guimarães.
} 
Que cada um de nós faça o íntimo e ignorado sacrifício de suas predileções, e queime silenciosamente os seus ídolos, quando perceber que estes ídolos e essas predileções são um entrave à obra de renovação da cultura geral. Amo tal escritor patrício do século XIX, pela magia irreprimível de seu estilo e pela genuína aristocracia de seu pensamento. Mas se considerar que este escritor é um desvio na orientação que deve seguir a mentalidade de meu país, para a qual um bom estilo é o mais vicioso dos dons, e a aristocracia um refinamento ainda impossível e indesejável, que devo fazer? A resposta é clara e reta: repudiá-lo. Chamemos este escritor pelo nome: é o grande Machado de Assis. . . . O escritor mais fino do Brasil será o menos representativo de todos. (A Revista 33)

Trinta anos mais tarde, na esteira das celebrações do cinquentenário de falecimento de Machado, Drummond volta a falar do escritor em pelo menos três ocasiões. Sua plataforma não é mais a da crítica-manifesto, mas sim a da crônica—gênero que há muito lhe era familiar e que fora igualmente praticado pelo Bruxo. Em $O$ Estado de $S$. Paulo de 5 Junho de 1958, comenta a "Inflação de Machado de Assis," quer dizer, das suas Obras Completas, que de 31 volumes passaria a contar com 103, incorporando textos que haviam sido refugados pelo próprio autor (projeto, aliás, não levado adiante). No Correio da Manhã de 1 Outubro de 1958, saúda os aniversariantes da semana: Machado de Assis, cinquenta anos de morte, Adolfo Casais Monteiro, cinquenta de vida, e Sérgio Milliet, setenta de nascimento. E no Correio da Manhã de 30 Agosto de 1959 critica a iniciativa da Academia Brasileira de Letras de construir um mausoléu para os seus membros e de transportar para lá os restos mortais do seu fundador. ${ }^{8}$

\footnotetext{
${ }^{8}$ Drummond volta ao tema uma semana depois, em tom entre jocoso e sério, na entrada de 07.09.1959 do seu diário pessoal (o qual, após cuidadosa edição, feita pelo próprio autor, seria tornado público em 1985, na forma do livro $O$ observador do escritório): "Ontem, encontro casual com Austregésilo de Athayde, na rua Primeiro de Março. Abraça-me, festivo, e entra logo no assunto: a trasladação dos despojos de Machado de Assis e Carolina para o mausoléu da Academia Brasileira. Assegura-me que não há qualquer declaração de acadêmico no sentido de promovê-la. Respondo-lhe citando a entrevista de Elmano Cardim ao Jornal do Comércio. A ideia seria colocar um monumento a Machado em lugar de honra do mausoléu coletivo, e marcar a transferência dos despojos para 21 de junho de 1989, data do sesquicentenário do nascimento do escritor - diz-me Athayde. Daqui a trinta anos. . . . Quem estiver vivo comparecerá. Certo? - pergunta ele, contando sem dúvida com a esperança fundada de eu não estar
} 
Os termos em que Drummond se refere a Machado são sempre respeitosos e expressam admiração, porém contidos, longe do elogio derramado; dir-se-ia que há neles quase um reconhecimento a contragosto, que se revela em tiradas sarcásticas, como nesta da primeira crônica do Correio da Manhã mencionada: "O que há de novo é que estamos machadianos, machadianíssimos, e de $30 \mathrm{em}$ 30 minutos cada um de nós se aplica o famoso emplasto Brás Cubas, em louvor do mestre; enquanto isso, o mestre, lá do sítio obscuro a que se recolheu, nos espia entre assustado e divertido." O que salta aos olhos, no entanto, é o tom empático com que o poeta começa a se referir ao romancista: em um caso (o da saudação aos aniversariantes), Drummond coloca Machado ao lado de outros dois autores vivos, destacando assim a sua atualidade; nos outros dois casos, sai em defesa de sua memória - e o faz a partir de um lugar de fala compartilhado pelos dois, o de escritor. De fato, a defesa do controle (inclusive post mortem) do autor sobre o conjunto da sua obra, feita no texto publicado em $O$ Estado de $S$. Paulo, é menos uma observação a posteriori da postura de Machado do que uma justificação a priori da postura que ele próprio viria a assumir.

Seis décadas depois do "parricídio" simbólico de Machado e após meio século vivendo no Rio de Janeiro, Drummond refere-se em outros termos ao autor, em entrevista concedida em 1984 a Maria Lúcia do Pazo. Em meio ao assunto das influência literárias, a entrevistadora lhe pergunta "E Machado, como é que ficou?" ao que ele responde:

Acho que houve uma intenção inconsciente minha de eliminar o Machado, porque de tal maneira ele me persegue que quando estou aqui conversando, de repente há uma interrupção qualquer, por motivo de um café ou coisa que o valha, então eu mergulho na estante, pego Machado e abro em qualquer página. É uma fatalidade na minha vida; talvez seja por isso que eu gostaria de esquecê-lo. (citado em Bortoloti)

vivo até lá para impugnar, embora sem êxito, a absurda transferência. (Machado manifestou, em testamento, o desejo de ser sepultado no túmulo de Carolina, o que exclui, naturalmente, qualquer veleidade de transferência de local.) Despedimo-nos com risadas de paz, mas eu continuo disposto a topar esta briga pelo respeito à vontade final do nosso escritor máximo, ameaçada de anulação pela fútil vaidade acadêmica. Nem Machado é propriedade da instituição que fundou." (O observador no escritório 118-119) 
Essa não foi, entretanto, a primeira vez em que Drummond declarou abertamente seu apreço por Machado, no ambiente distenso de uma entrevista. Em 1954 ele deu oito depoimentos a Lya Cavalcanti, na Rádio do Ministério da Educação e Cultura, em série intitulada "Quase memórias", que viria a ser transcrita e publicada apenas em 1986, um ano antes de sua morte, no livro Tempo, vida, poesia. Aí, ao lembrar das suas primeiras leituras "sérias," que lhe chegavam pelas mãos do irmão Altivo, ele comenta:

Passar de Fialho [de Almeida] a Eça [de Queiroz] foi um salto de vara curta: fiquei freguês do segundo e, pela graça de Deus, cheguei cedinho a Machado de Assis. Deste não me separaria nunca, embora vez por outra lhe tenha feito umas má-criações. Justifico-me: amor nenhum dispensa uma gota de ácido. É mesmo o sinal menos que prova, pela insignificância e transitoriedade, a grandeza do sinal mais. Se me derem Machado na tal ilha deserta, estou satisfeito; o resto que se dane, embora o resto seja tanta coisa amorável. (Prosa seleta 1217-1218)

Não cabe aqui fazer uma tentativa de psicanálise do sujeito Carlos Drummond de Andrade, a fim de entender o seu relacionamento com o paradigma paternoembora seja evidente que, à postura de rejeição de tal papel na juventude, sucede um movimento de incorporação desse mesmo papel na maturidade. O recurso às declarações extraliterárias do poeta serve, contudo, para confirmar a intuição de que, no processo de criação literária, certas afinidades profundas revelam-se mais fortes do que alguns rechaços programáticos; e de que, muitas vezes à revelia dos autores, "de tudo quanto foi ... passo caprichoso / na vida [restarão], pois o resto se esfuma" (Reunião 165) "conversações do papel e para o papel."

\section{Obras Citadas}

Agamben, Giorgio. A linguagem e a morte. Trad. Antônio Negri. Belo Horizonte:

U Federal de Minas Gerais, 2006. Impresso.

Andrade, Carlos Drummond. "Sobre a tradição em literatura." A Revista 1(1925):

32-3. Impresso.

-. Reunião: 10 livros de poesia. Rio de Janeiro: Olympio, 1977. Impresso. 
—. O observador no escritório: páginas de diário. Rio de Janeiro: Record, 1985. Impresso.

-. Prosa seleta. Rio de Janeiro: Nova Aguilar, 2003 Impresso.

Barthes, Roland. O prazer do texto. Trad. J. Guinsburg. São Paulo: Perspectiva, 2006. Impresso.

Bloom, Harold. A angústia da influência: uma teoria da poesia. Trad. Arthur Nestrovski. Rio de Janeiro: Imago, 1991. Impresso.

Blanchot, Maurice. A conversa infinita. Trad. João Moura, Jr. São Paulo: Escuta, 2007. Impresso.

Bortoloti, Marcelo. "A voz do poeta: erotismo, poesia e psicanálise em entrevista inédita de Drummond." Folha de S. Paulo. 8 Julho de 2012. Web. 2 Fevereiro de 2015.

Bosi, Alfredo. “A máscara e a fenda." Machado de Assis, o enigma do olhar. São Paulo: Martins Fontes, 2007. 73-125. Impresso.

—. “A máquina do mundo' entre o símbolo e a alegoria.” Céu, Inferno: ensaios de crítica literária e ideológica. São Paulo: Editora 34, 2003. 99-121. Impresso.

Candido, Antonio. Formação da literatura brasileira: momentos decisivos. São Paulo: Ouro sobre Azul, 2006. Impresso.

Correia, Marlene de Castro. Drummond - a magia lúcida. Rio de Janeiro: Zahar, 2002. Impresso.

Garcia, Othon Moacyr. Esfinge clara, palavra-puxa-palavra em Carlos Drummond de Andrade. Rio de Janeiro: São José, 1955. Impresso.

Guimarães, Hélio de Seixas. Os leitores de Machado de Assis: o romance machadiano e o público de literatura no século XIX. São Paulo: Nankin e Edusp, 2012. Impresso.

—. "Drummond se rende a Machado." Valor Econômico. 14 Setembro de 2012. Web. 28 Fevereiro de 2015.

Lima, Luiz Costa. Lira e antilira: Mário, Drummond e Cabral. Rio de Janeiro: Civilização Brasileira, 1968. Impresso.

Machado de Assis, Joaquim Maria. Páginas recolhidas. Rio de Janeiro: H. Garnier, 1899. Impresso.

-. Relíquias de casa velha. Rio de Janeiro: H. Garnier, 1906. Impresso.

- Romances e contos em hipertexto. Ed. Marta de Senna. 2009. Web. 28 Fevereiro de 2015. 
Maya, Alcides. Machado de Assis (algumas notas sobre o humour). Rio de Janeiro: Silva, 1912. Impresso.

Merquior, José Guilherme. Verso, universo em Carlos Drummond de Andrade. Rio de Janeiro: José Olympio, 1976. Impresso.

Meyer, Augusto. "O homem subterrâneo." Machado de Assis. Rio de Janeiro: Organização Simões, 1952. 13-20. Impresso.

Rifaterre, Michel. “The Intertextual Unconscious.” Critical Inquiry 13.2 (1987): 371-85. Impresso.

Santiago, Silviano. Uma literatura nos trópicos: ensaios sobre dependência cultural. São Paulo: Perspectiva, 1978. Impresso.

Senna, Marta de. O olhar oblíquo do Bruxo. Rio de Janeiro: Língua Geral, 2008. Impresso.

Zilberman, Regina. "Memorialismo fictício de Machado de Assis a Graciliano Ramos-Dom Casmurro e São Bernardo." Machado de Assis em Linha. 2 Dezembro de 2008. Web. 9 Outubro de 2012. 